\title{
Selected Legumes Used As Summer Cover Crops ${ }^{1}$
}

\section{Jim Rich, David Wright, Jim Marois, and Dick Sprenkel ${ }^{2}$ \\ Cover Crop Use}

Cover crops are generally planted after a primary (cash) crop for one or more of the following reasons: erosion control, organic matter accumulation, improved soil tilth, pest suppression (weed, disease, nematode, and insect), and nitrogen production. Optimally, a cover crop will provide a wide range of most or all of the previously mentioned benefits, even if the main reason for planting it was more specific, for example erosion control. Certainly, a cover crop that may become a weed problem or one that increases pest problems such as nematodes should not be planted. The cover crops below also can be incorporated into soil as green manures for the reasons listed above, and the main difference is that incorporation, while green, provides additional organic material and nutrients to the soil. The eight cover/green manure crops described herein have been shown to provide several benefits to a succeeding crop.

\section{Nitrogen Fixation}

Bacteria in the soil, mainly in the genus Rhizobium, attach to roots of legumes and fix nitrogen from the air. The association between leguminous plants and the bacteria is described as symbiotic, indicating that both bacteria and the plants are mutually benefited. Legumes obtain nitrogen fixed by the bacteria while the bacteria receive carbohydrates and other nutrients from the plant. Due to this nitrogen fixation, legumes do not usually need nitrogen fertilization, unlike plants that are not leguminous. The Rhizobium bacteria are widely distributed in nature, however, improved strains have been developed that are more vigorous and produce more nitrogen for legumes. Most legumes grow best when seed are inoculated with commercial preparations of Rhizobium, in this case, inoculum derived from the cowpea group. Rhizobium inoculum does not have to be added for each planting of the same crop. However, it should be applied to seeds when planting in soils where none has ever been added or where inoculum application was more than five years prior to planting.

1. This document is ENY-688 (IN483), one of a series of the Department of Entomology and Nematology, Florida Cooperative Extension Service, Institute of Food and Agricultural Sciences, University of Florida, Publication Date: August 2003. Please visit the EDIS Web site at http://edis.ifas.ufl.edu.

2. Jim Rich, professor, Entomology and Nematology Department, David Wright, professor, Agronomy Department, Jim Marois, professor, Plant Pathology Department, Dick Sprenkel, professor, Entomology and Nematology Department; North Florida Research and Education Center-Quincy, Cooperative Extension Service, Institute of Food and Agricultural Sciences, University of Flordia, Gainesville, 32611. 


\section{Nematode Resistance}

Plant-parasitic nematodes are major soil-borne pests in ornamental, home garden, field crop and vegetable production systems in Florida.

Recommendations for control include crop rotation with plants that are non-hosts or resistant to the prevalent nematode species at the site. Usually, two or more years of rotation crops are needed to significantly reduce nematode damage to the primary crop. Cover crops, however, are usually planted during the time of year when the primary crop(s) is not growing. Due to the need for lengthy rotations for nematode management, simply growing a cover crop is not sufficient to adequately reduce nematode populations. Use of these crops, however, are helpful to: 1) suppress weeds that may allow reproduction of nematodes to higher levels than in the previous primary crop; 2) increase organic matter which promotes greater nutrient and water holding capacity of the soil, thus helping plants tolerate nematode parasitism; and 3) a few cover crops such as velvet bean are antagonistic to nematodes and actually reduce populations in the soil. Green manuring a cover crop provides similar benefits, plus upon turning, the organic matter stimulates biological control agents of nematodes (mainly fungi) in the soil as well.

\section{Planting Dates and Methods}

Planting dates for crops vary in Florida due to the varying climatic conditions of the peninsula. The recommended planting dates in this article are most accurate for northern Florida, and earlier planting dates may be acceptable in more southern areas of the state. Also, most seed of the cover crops listed below are small and should be covered quite shallow. Best germination is achieved with a well-prepared, firm and moist seedbed. However, minimum tillage techniques are suitable although greater care must be taken in planting. A $20 \%$ greater seeding rate is also recommended.

\section{Alyceclover}

\section{Scientific Name: Alysicarpus vaginalis}

Alyceclover is a summer annual legume long grown in Florida as a grazing and hay crop. The plant may grow to a height of three feet at maturity. While traditionally a forage and hay crop, alyceclover is also used as a cover/green manure crop, and provides the advantages of good nitrogen and biomass production (Table 1). Broadcast seeding rates are 15-20 lbs/acre, and seed should be covered one-fourth to one-half inch deep. Seed can be planted by drilling or broadcasting and cultipacking into a well-prepared seedbed. Planting may begin in April and extend through early June when adequate moisture is available for good germination. Alyceclover grows best in well-drained soils with moderate to good fertility levels. The crop does not tolerate acid soils well, and $\mathrm{pH}$ should be in the range of 5.5 to 6.5 for best growth. Few disease problems or insect pests affect crop establishment and subsequent growth. However, the plant is highly susceptible to root-knot and sting nematodes and sites with a history of nematode problems should be avoided (Table 2). In many cases, susceptibility to nematodes render this crop less than desirable as a cover crop. Alyceclover will reseed when allowed to grow to maturity, and this should be considered when determining crop termination to prevent creating a potential weed problem in succeeding crops. For further information on cultural practices, go to:

http://edis.ifas.ufl.edu/DS123.

\section{American Joint Vetch}

\section{Scientific Name: Aeschynomene americana; Other Commom Names: Joint Vetch, Deervetch, Aeschynomene}

American joint vetch is native to the southeastern U.S. and is a reseeding summer annual. The plant grows upright and may obtain a height of 4-6 feet. Joint vetch is very palatable to livestock and is also used as a food plant for wildlife such as ducks, quail, dove, and deer. Additionally, American joint vetch can be used as a cover/green manure crop providing advantages of good nitrogen fixation and biomass production (Table 1). Broadcast seeding rates are 5-8 pounds/acre for hulled seed and 20-25 pounds/acre of 
non-hulled seed. For good stand establishment, plant seed $1 / 2$ to $11 / 2$ inches deep in a well-prepared seedbed as described for alyceclover. Hulled seed germinate intermittently, with immediate germination of about 5-10\%. Planting may begin in April and continue through June in north Florida. The main problem with stand establishment is lack of moisture since few seedling disease or insect problems have been encountered. Joint vetch grows best in moist, flatwood areas in warm fertile soils. The crop responds well to fertilization although as a legume, does not require addition of nitrogen. Joint vetch grows best at a $\mathrm{pH}$ of $5+$ to 6.5 . Remember, the plant reseeds, and this should be considered when determining crop termination, and choice of future crop to be planted. Joint vetch is an excellent rotation crop to reduce populations of root-knot and sting nematodes (Table 2). For more information on cultural practices, go to:

http://edis.ifas.ufl.edu/AA189.

\section{Butterfly Pea}

\section{Scientific Name: Clitoria ternatea; Other Common Names: Tropical alfalfa, Blue pea}

Butterfly pea is a perennial crop plant and is widely distributed in the humid lowland tropics of Africa, Asia, Central, and South America and widely grown for use in dairy, cattle and horse industries. The use of this crop for grazing and hay in the southeast has only recently been explored. However, it has shown potential as a substitute to imported alfalfa hay. Butterfly pea is grown as a summer annual due to winterkill. The plant is also grown as an annual ornamental. Butterfly pea is very drought tolerant and may be grown on most soil types except those that are frequently waterlogged. Production requirements for butterfly pea are similar to those of alfalfa. For best plant growth, a $\mathrm{pH}$ of greater than 6.0 is needed, and the plant responds well to moderate-high fertility levels. Although butterfly pea is a legume, growth of the crop may increase by adding nitrogen fertilization. Broadcast seeding rates are 20-25 lbs/acre, and planting depth should be three-fourths to one inch deep. Planting may begin in April and continue into June. Since butterfly pea is a relatively new crop to Florida, little information is available on insect and disease problems for stand establishment or plant growth. Few problems are suspected, however, due to experience in other parts of the world. Butterfly pea has been shown to be resistant to the peanut root knot nematode (Table 2). For further information on this crop, go to: http://www.pi.csiro.au/ahpc/grasses/pdf/milgarra.pdf.

For information on ornamental uses, go to: http://www.plantoftheweek.org/week043.shtml.

\section{Hairy Indigo}

\section{Scientific Name: Indigofera hirsuta}

Hairy indigo is an annual reseeding legume that can grow to about 7 feet tall and is native to tropical Asia. The plant is palatable to livestock and can be used for grazing or hay. For most farmers, however, it is a continuing weed problem in field and vegetable crops. The crop can be a good summer annual cover/green manure crop, particularly on sandy soils since it is quite drought tolerant. Hairy indigo does not tolerate wet soils. The plant is moderately resistant to several species of nematodes (Table 2). Recommended broadcast seeding rate into well-prepared soil is 6-8 lbs/acre with seed planted $1 / 4$ " to $1 / 2$ " deep. Seed germination, like American joint vetch, will be intermittent with immediate germination often ranging from only $10-20 \%$. Planting can begin in April and continue through June in Florida. Adequate moisture is needed for good germination and few seedling disease problems or insects affect stand establishment or crop growth. The crop responds to moderate fertilization, although it will produce adequately if residual soil fertility is adequate. Hairy indigo grows well within $\mathrm{pH}$ ranges for normal production of other crops. Remember, hairy indigo reseeds and this should be considered when determining crop termination to prevent the plant from becoming a weed problem. Also, the plant produces hard seed, so some seed planted in one year will carry over and germinate in the next year. To reduce this, plant only scarified seed that allows the vast majority of seed to germinate in the year of seeding. For more information on cultural practices and use as a forage crop, go to: http://edis.ifas.ufl.edu/AG156. 


\section{Partridge Pea}

\section{Scientific Name:Cassia fasciculata; Other Common Names: Showy Partridge Pea}

Partridge pea is a reseeding annual widely spread throughout the eastern U.S. The plant may obtain a height of 6 feet although typical heights are closer to 3 feet. In the past, the partridge pea has been planted as a wildlife food for quail, hence its name. Broadcast scarified seed at the rate of 10 to $15 \mathrm{lbs} / \mathrm{acre}$. A grain drill may be used or surface broadcast the seed and lightly disc or cultipack. Plant seeds one-half inch deep into warm, moist soil. Planting dates between early March and early June achieve best results, and partridge pea will grow on a wide range of soils, including those that are nutrient poor. However, moist, sandy soils are best suited for partridge pea growth. Due to the shallow seeding, adequate soil moisture is required for a good stand. The plant has few diseases or insect problems both for stand establishment and plant growth. Partridge pea responds to moderate fertilization but when used as a cover crop, residual fertility is generally sufficient. Please note, partridge pea both reseeds and has hard seed. Use only scarified seed and destroy the crop before seed production. Partridge pea is resistant to root-knot nematodes (Table 2). For more information on cultural practices, go to:

http://www.aces.edu/department/extcomm/ publications/anr/ANR-610/anr610main.html

\section{Sericea Lespedeza}

\section{Scientific Name: Lespedeza cuneata}

Sericea lespedeza is a perennial crop plant that is used as a warm season grazing crop but can be planted as an annual summer cover/green manure crop. Several improved varieties are available including AU Grazer, Serala, Interstate 76, Interstate, AU Donnelly, AU Lotan, and Serala 76. Broadcast seeding rates are 25-30 lbs/acre of unhulled seed, and seed should be placed about one-fourth inch deep. Seed can be drilled into a well-prepared seedbed or alternatively, broadcast with a spreader followed by a light discing or cultipacking. Planting may begin after the threat of frost has passed in the spring through May. Moisture is critical for stand establishment since seed are very shallow. Sericea lespedeza is adapted to a wide range of soils, fertility and $\mathrm{pH}$ levels. The plant responds to moderate levels of fertility but can produce quite well from residual fertility. After establishment, the plant is quite drought tolerant. Few disease or insect problems have been encountered with this crop. Sericea is a prolific seed producer and will reseed, thus crop termination should be prior to seed maturity. The plant is resistant to the southern root-knot nematode (Table 2). For more information on cultural practices, go to: www.aces.edu/department/cotton/.

\section{Sunnhemp}

\section{Scientific Name: Crotolaria juncea; Other Common Names: Indian Hemp, Brown Hemp}

Sunnhemp is a rapidly growing annual and may grow to a height of 10 feet. It produces abundant biomass (Table 1) and has been used as a source of cellulose for manufacture of products such as bags and rope. Due to the high biomass production, sunnhemp is an excellent annual cover/green manure crop that provides the added advantages of high nitrogen fixation and nematode resistance (Table $1 \&$ 2 ). The rapid growth of sunnhemp is also of value in weed suppression. Seed are generally planted at a broadcast rate of 15-30 lbs/acre and should be planted 1 to 1 1/2 inches deep into well-drained, moist soil. Planting dates are from March 15 to April 15 in Florida. The crop responds to fertilization but grows well from residual soil fertility and at a range of normal cropping $\mathrm{pH}$ values of 5.8-6.2. Few insect or disease problems affect establishment or plant production of the crop. Sunnhemp is resistant to southern root-knot and sting nematodes. The crop is best turned under as a green manure or mowed about 70 days after planting; otherwise, the stalks and stems become quite woody and are slow to decompose in the soil.

\section{Velvet Bean}

\section{Scientific Name: Mucana deeringana}

Velvet bean is an annual plant native to the tropics. The plant was first grown in Florida around 1890 and subsequently spread throughout the southern U.S. as a grazing and green manure crop. 
Because of its tropical nature, velvet bean requires a long frost-free growing season and has maturities ranging from 100 days to over 250 days. With the exception of some bush varieties, the growth habit of the plant is a vine and vines attain a length of 10-25 feet. Stems, leaves, and pods of velvet bean possess numerous hairs that sting upon touching. Seed of velvet bean are large, about 4-5 times bigger than soybean. Velvet bean can be planted from April to June, and if planted for a cover/green manure crop, $30-35 \mathrm{lbs} . / \mathrm{acre}$ of seed is needed in rows 30-40 inches wide. Seed may be planted from one and one-half to three inches deep. The crop grows relatively well on droughty, sandy, and somewhat infertile soils, hence fertilizer is seldom applied to the crop. Velvet bean can add a substantial amount of nitrogen to the soil, and also is both root-knot nematode resistant and antagonistic to these nematodes (Table 2). Velvet bean generally is free of disease problems and insect pests. The velvet bean caterpillar is an important pest of many crops and can be a major pest, occurring mainly in late summer. 
Table 1. Soil nitrogen and biomass production potential of eight leguminous cover crops.

\begin{tabular}{|c|c|c|c|}
\hline Cover Crop & Crop Uses ${ }^{1}$ & $\begin{array}{l}\text { Soil N } \\
\text { lbs/acre }^{2}\end{array}$ & $\begin{array}{l}\text { Biomass } \\
\text { lbs/acre }^{2}\end{array}$ \\
\hline Alyceclover & $\mathrm{G}, \mathrm{H}, \mathrm{WLF}$ & $40-150$ & $3000-8000$ \\
\hline $\begin{array}{l}\text { American } \\
\text { joint vetch }\end{array}$ & $\mathrm{G}, \mathrm{H}, \mathrm{WLF}$ & $40-100$ & $4000-8000$ \\
\hline Butterfly pea & $\mathrm{G}, \mathrm{H}$ & ------- & ------ \\
\hline Hairy indigo & $\mathrm{G}, \mathrm{H}$ & $40-80$ & $3000-8000$ \\
\hline Partridge pea & WLF & $20-60$ & $2000-6000$ \\
\hline $\begin{array}{l}\text { Sericea } \\
\text { lespedeza }\end{array}$ & $\mathrm{H}, \mathrm{WLF}$ & $40-80$ & $3000-8000$ \\
\hline Sunnhemp & None & $120-200$ & $8000-14000$ \\
\hline Velvet bean & $\mathrm{G}$ & ------- & ------- \\
\hline \multicolumn{4}{|c|}{$\begin{array}{l}{ }^{1} \text { In addition to cover/green manure crop, several of the plants can be used for other } \\
\text { purposes including grazing }(\mathrm{G}) \text {, hay }(\mathrm{H}) \text {, and/or wildlife food (WLF) } \\
{ }^{2} \text { Nitrogen }(\mathrm{N}) \text { and biomass production will vary widely dependent upon growing } \\
\text { conditions; data presented are general in nature. }\end{array}$} \\
\hline
\end{tabular}

Table 2. Host status of eight summer leguminous cover crops to root-knot and sting nematodes. ${ }^{1}$

\begin{tabular}{|c|c|c|c|c|}
\hline Cover Crop & $\begin{array}{l}\text { Southern } \\
\text { root-knot }\end{array}$ & $\begin{array}{l}\text { Peanut } \\
\text { root-knot }\end{array}$ & $\begin{array}{r}\text { Javanese } \\
\text { root-knot }\end{array}$ & $\begin{array}{c}\text { Sting } \\
\text { nematode }\end{array}$ \\
\hline Alyceclover & $S$ & $S$ & - & $S$ \\
\hline $\begin{array}{l}\text { American } \\
\text { joint vetch }\end{array}$ & $\mathrm{R}$ & $\mathrm{R}$ & $\mathrm{R}$ & $\mathrm{R}$ \\
\hline Butterfly pea & - & $\mathrm{R}$ & - & - \\
\hline Hairy indigo & $\mathrm{R}$ & $\mathrm{R}$ & - & $\mathrm{R}$ \\
\hline Partridge pea & $\mathrm{R}$ & $\mathrm{R}$ & $\mathrm{R}$ & $\mathrm{R}$ \\
\hline $\begin{array}{l}\text { Sericea } \\
\text { lespedeza }\end{array}$ & $\mathrm{R}$ & $\mathrm{R}$ & - & $\mathrm{R}$ \\
\hline Sunnhemp & $\mathrm{R}$ & - & - & $\mathrm{R}$ \\
\hline Velvet bean & $\mathrm{R}$ & $\mathrm{R}$ & $\mathrm{R}$ & $\mathrm{R}$ \\
\hline \multicolumn{5}{|c|}{$\begin{array}{l}{ }^{1} \text { Root-knot and sting nematode host status are reflected by } R=\text { resistant (reduces } \\
\text { populations), } S=\text { susceptible (can increase populations), and dash }(-)=\text { unknown host } \\
\text { status. }\end{array}$} \\
\hline
\end{tabular}

